Article by an MPIfG researcher

Alison Johnston, Aidan Regan: European Monetary Integration and the Incompatibility of National Varieties of Capitalism. In: Journal of Common Market Studies 54(2), 318-336 (2016). Wiley-Blackwell

The original publication is available at the publisher's web site: http://dx.doi.org/10.1111/jcms.12289

\title{
European Monetary Integration and the Incompatibility of National Varieties of Capitalism*
}

\author{
ALISON JOHNSTON ${ }^{1}$ and AIDAN REGAN ${ }^{2}$
}

${ }^{1}$ Oregon State University. ${ }^{2}$ University College Dublin

\begin{abstract}
The Varieties of Capitalism literature offers two competing hypotheses on institutional resilience. One argues that globalization promotes convergence towards a neo-liberal system. Another stipulates that diverse capitalist regimes promote different comparative advantages, enabling diverse political economies to co-exist. In this article, we argue that the compatibility of diverse models of capitalism is contingent upon monetary regime. We examine how different currency regimes influence the mutual co-existence of export-led growth models (euro core) and domestic demand-led growth models (euro periphery). Under EMU, we find that these two models have become increasing incompatible, as unsustainable divergences in external balances have emerged between them. We hypothesize that external imbalances between these two growth regimes did not emerge prior to EMU because of the presence of two inflation adjustment mechanisms in the real exchange rate; the nominal exchange rate (in soft currency regimes) and national central banks' promotion of inflation convergence (in hard currency regimes).
\end{abstract}

Keywords: Comparative political economy, European monetary union, eurozone crisis, growth regimes, models of capitalism

Europe's sovereign debt crisis has highlighted the limits of European monetary integration in promoting economic and political unity. Economic fissures have emerged between EMU's northern (core) and southern (peripheral) member states: ${ }^{1}$ while the former group of countries has emerged from the current crisis unscathed with regard to speculation in international bond markets, the latter group has become subject to intense speculative pressure. In return for bailout assistance from the 'Troika' (the EU Commission, European Central Bank, and the International Monetary Fund), member states in the periphery are forced to impose harsh austerity measures, which have significantly reduced standards of living and heightened doubts about the desirability of further European integration among electorates.

The lack of macroeconomic adjustment tools in EMU's periphery prompts the question whether European monetary integration is capable of producing welfare-improving outcomes for member states with diverse national economic systems. We argue that monetary integration may have rendered the diverse co-existence of national varieties

\footnotetext{
* We thank Martin Höpner, Erik Jones, and Fritz Scharpf for their incredibly helpful comments. Any errors lie solely with the authors.

${ }^{1}$ In this paper, we use the terms 'core', 'northern' and 'export-led models' interchangeably to describe the EMU economies that have emerged unscathed from the crisis (Austria, Belgium, Finland, Germany, the Netherlands and to a lesser degree France). Likewise, we use the terms 'periphery', 'southern' and 'domestic demand-led models' to describe EMU countries that have fallen into crisis (Greece, Italy, Portugal, Spain and to a lesser extent Ireland).
} 
of capitalism incompatible. The domestic organization of different political economies in the north and south has interacted with transnational European monetary policy to produce a persistent, unsustainable divergence in trade and external lending, which has been cited by many as an underlying instigator of speculative divergence among EMU member states (Obstfeld and Rogoff, 2009; Shambaugh et al., 2012; Scharpf 2011). We trace this divergence to the incompatibility of two distinct growth regimes that produce different inflation rates; high inflation-prone, domestic demand-led models, which predominate in the 'mixed market' economies of southern Europe, and low inflation-prone, export-led models, which dominate northern co-ordinated market economies.

Prior to the formation of EMU, these two different inflationary growth regimes were able to co-exist without producing significant external lending and current account imbalances between each other (see Figure 1). Rather, it was the political drive toward European monetary integration that combined these distinct economic growth models into a single currency that led to large, persistent and ultimately unsustainable imbalances in trade and external lending. In this regard, the euro crisis can partially be traced to the asymmetric effects of joining together qualitatively distinct growth regimes, or national varieties of capitalism, with different inflation performances into a monetary union.

We argue that two factors explain why inflation-prone and inflation-moderating growth regimes could co-exist prior to the formation of the EMU but not afterwards. The first is due to the presence of the nominal exchange rate within soft-peg or flexible exchange rate systems (i.e. the euro periphery during the early days of the EMS, or European Monetary

Figure 1: External Balances vis-à-vis All Trading Partners in EMU's Northern and Southern Economies (1980-2014) Source: EU AMECO Database (2014) Note: Northern economies include Austria, Belgium, Finland, France, Germany and the Netherlands. Southern economies include Greece, Ireland, Italy, Portugal and Spain. We present southern external lending balances with and without Greece because that the country lacked external lending data before 1995 .

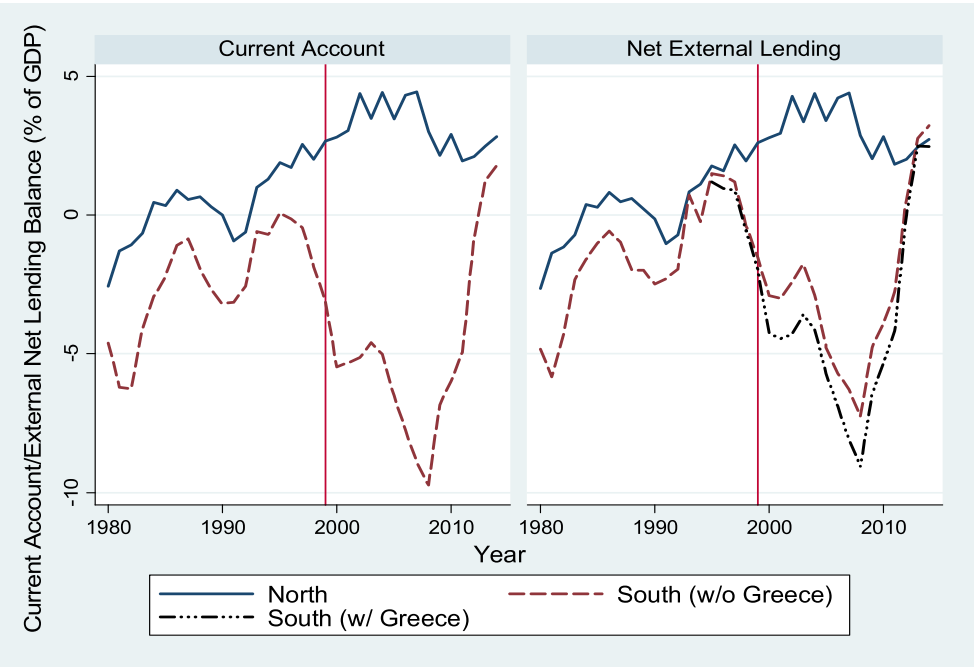


System). Under this monetary arrangement, growth models with higher inflation had greater leeway in promoting economic adjustment through currency depreciations/devaluations. ${ }^{2}$ Second, in hard-currency exchange rate systems where the nominal exchange rate is fixed, competitive realignment between EMU's diverse growth models was facilitated via inflation-averse, national central banks that promoted inflation and real exchange rate convergence among participating Member States. Once the EMU removed these two mechanisms, imbalances in the real exchange rate, driven purely by divergences in national inflation, grew unchecked, leading to persistent external imbalances within EMU.

\section{The Loss of Price Competitiveness: Cause or Outcome of the Euro Crisis?}

Two competing, although not mutually exclusive, literatures attempt to explain the origins of the Eurozone crisis by examining external macroeconomic imbalances between EMU's north and south. The competitiveness argument focuses on how current account imbalances led to crisis exposure in EMU's periphery countries (Obstfeld and Rogoff, 2009; Belke and Dreger, 2011; Shambaugh et al., 2012). The core problem suggested here is that the eurozone crisis is a structural imbalance between export-led countries with current account surpluses and domestic demand-led countries with current account deficits. In order to finance these deficits, the south needed to externally borrow through the capital account (see Figure 1). Because of a strong home bias in European investment, the external financing of the south's current account deficits during the EMU's first decade largely stemmed from northern lending. These current account deficits are not a problem in themselves and can be sustainable if external borrowing is used to enhance productivity in the export sector, thereby enhancing long-term productivity. But in the eurozone periphery, this borrowing was channeled into non-tradable sectors (construction in Ireland and Spain and the public sector in Greece) that are unable to generate the largesse needed to underpin future current account surpluses. The persistence of these current account deficits in the euro periphery prompted markets to doubt their total solvency, exposing them to crisis.

Hall (2012), Höpner (2013) and Johnston et al. (2014) provide a more nuanced institutional view as to what gave rise to these competitiveness imbalances in the pre-crisis years of the EMU. They argue that the EMU's northern economies used features of their qualitatively distinct corporatist wage-setting institutions to promote an export-oriented growth regime. Co-ordinated wage-setting institutions constrained the growth of labour costs and helped to deliver low inflation, which promoted real exchange rate competitiveness. Because EMU's northern economies were able to produce such high levels of wage moderation through their co-ordinated collective bargaining regimes, these Member States produced persistent current account surpluses that were mirrored in the south's current account deficits. From the perspective of European integration, the promotion of national wage competition in CMEs (co-ordinated market economies) undermined the export competitiveness of non-CME countries sharing the same currency.

The loss-of-competitiveness argument explains rising financial and trade imbalances between the EMU's creditor and debtor countries as the causal factor via the current

\footnotetext{
${ }^{2}$ This is not to suggest that devaluation/revaluation is an optimal strategy to improve cost competitiveness. But it does have different distributional implications for the downward adjustment in wages and public spending.
} 
account. A second explanation, however, found within the broader financial liberalization literature, argues the opposite. The divergence of real exchange rates, from this perspective, was a consequence of credit expansion. Without the existence of a coherent financial and/or banking union across Europe, unsustainable imbalances between the north and south started in the capital account (Lane, 2012; Burda, 2013; Jones, 2014 and 2015). The source of rising economic imbalances between countries in the EMU's core and its periphery stems from the influence of monetary union on nominal interest rates, which expanded the availability of cheap credit for the private and public sector, and in turn led to worsening current account balances. ${ }^{3}$

In promoting the relinquishment of capital controls in the 1990s and convergence in nominal exchange rates and interest rates, the EMU's southern European countries witnessed significant reductions in borrowing costs before their entry into the EMU. Coupled with a greater availability of financial products, this access to cheap credit fuelled consumption and real-estate booms in the euro periphery. Greater access to cheap credit increased disposable income in domestic demand-led countries and led to rises in wages, in order for households to maintain consumption. These wage increases, in turn, placed upward pressures on inflation, which contributed to increases in the real exchange rate in domestic demand-led economies that were persistently above those in export-led economies between 1999 and 2008 (EU AMECO Database, 2014).

\section{Rethinking the Causal Mechanism: The Timing and Internal Nature of the Crisis}

Both the competitiveness and financial accounts of the European debt crisis highlight important determinants of the crisis that stem from external imbalances between the EMU member states. Despite these inroads, both exhibit failings. The competitiveness hypothesis fails to adequately explain why these persistent imbalances only emerged with the creation of the single currency. The different growth models within EMU and the divergence in unit labour costs that they produced existed well before the launch of the euro. While competitiveness advocates acknowledge that the periphery's incapacity to devalue under a common currency facilitated persistent inflation and competitive divergence, this inability to devalue was also present under Maastricht, when northern and southern external imbalances still remained contained. During the process of European monetary integration in the 1980s and 1990s, these two different 'varieties of capitalism' co-existed but failed to produce significant external imbalances, despite having very different rates of inflation and nominal unit labour cost growth.

The financial account of the crisis does a better job at explaining the timing of the crisis during the late 1990s and 2000s. The higher interest rate premiums associated with more volatile currencies in the 1990s and the significant reduction of such premiums during the Maastricht convergence period explain why persistent borrowing imbalances between EMU's north and south only emerged in the 2000s. However, the financial literature fails

\footnotetext{
${ }^{3}$ A third (fiscal) view of the origins of the crisis argues that divergent patterns in public borrowing prior to the financial crisis explain divergent speculative exposure. This rests on a similar premise as the financial literature: low interest rates and the lack of proper enforcement of the Stability and Growth Pact increased sovereigns' incentive to borrow, promoting high deficits and public debt accumulation (see Buiter and Rahbari, 2010 for an overview). Empirically, however, the fiscal view is so weak in explaining crisis exposure for a number of EMU economies that we do not seriously consider it here (see Johnston et al., 2014). Scholars in the financial literature agree that speculative attack was not precipitated by debt accumulation in the public sector alone.
} 
Figure 2: Extra- and Inter-EU Net Exports for Northern and Southern Economies (1980-2014) Source: EU AMECO Database (2014) Note: Northern economies include Austria, Belgium, Finland, France, Germany and the Netherlands. Southern economies include Greece, Ireland, Italy, Portugal and Spain.

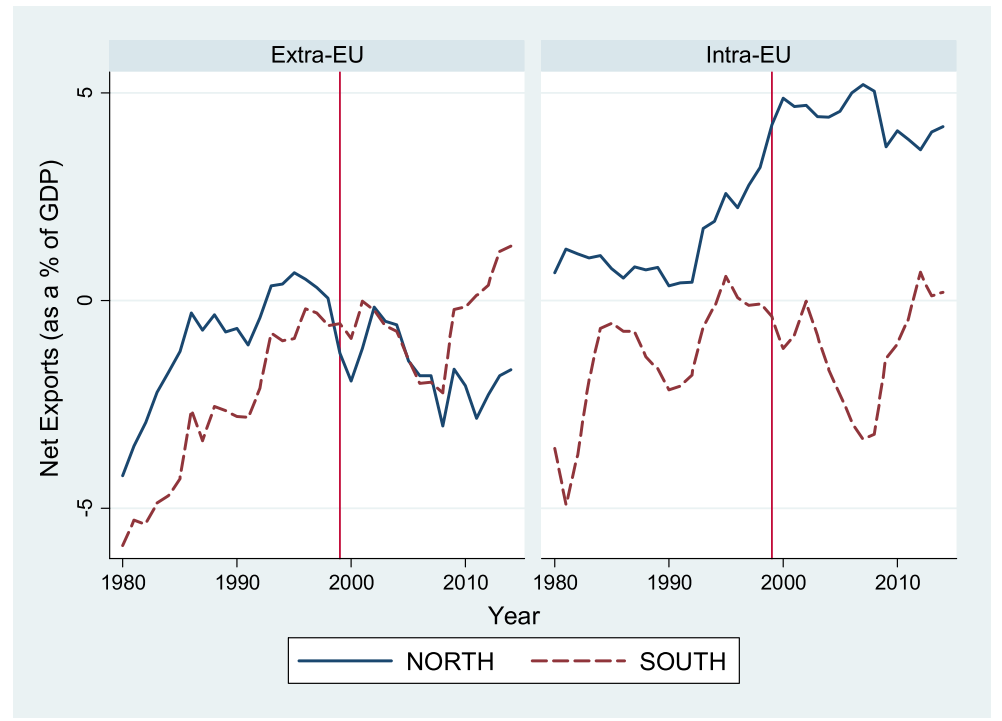

to adequately explain two additional phenomena. First, it does not account for why northern eurozone countries became external net lenders (savers) under monetary union, given that they too witnessed declines in nominal interest rates and greater access to cheap credit during the 1990s. Second, it fails to explain the 'location' bias of southern borrowing. Reductions in nominal interest rates should have increased the south's demand for credit from all international financial lenders. However, the supply of credit to the euro periphery possessed a strong intra-euro regional bias and largely originated from savings in Europe's northern banks (Gros, 2012).

The importance of this internal relationship between the north and south is also visible in intra- and extra-EU trade statistics, which can partially map the regional imbalances in international capital flows. ${ }^{4}$ Mirroring the current account and external lending imbalances between EMU's north and south after 1999 (see in Figure 2), the growing gap between intra-EU trade deficits in the south and intra-EU trade surpluses in the north is noticeably prominent after the creation of the single currency. However, southern domestic demanddriven and northern export-driven economies perform almost identically in regards to trade balances vis-à-vis non-EU countries after $1999 .^{5}$ It was only after the crisis that the south and north diverged in their net export performance vis-à-vis non-EU countries. This was (partially) a result of southern firms having to look outside Europe for markets, given

\footnotetext{
${ }^{4}$ Data on national capital flow by country of origin is lacking, so we use national trade data to approximate capital imbalances run by EMU's northern and southern economies vis-à-vis their EU and non-EU trading partners.

${ }^{5}$ This should not be surprising. Both southern and northern EMU countries possessed a more equal playing field in their extra-EU trade performance because they shared the same nominal exchange rate vis-à-vis non-EMU nations.
} 
the persistence of demand suppression in the wider eurozone, and the collapse in domestic demand as a consequence of austerity. The important point to note is that the divergences in current and capital accounts that emerged between the north and south are an internal relation between different growth regimes. We will now provide a theoretical account of why these imbalances between EMU's domestic demand-led (high inflation prone) and export-led (low inflation prone) regimes only emerged under the single currency.

\section{A Theoretical Account of Currency Regimes and the Incompatibility of Growth Models}

We assume that EMU's original entrants ${ }^{6}$ are constituted by two qualitatively distinct capitalist growth regimes, which are sustained by distinct political/producer coalitions (Hall 2012). One model is driven by the economic prominence of the export sector and rests within the institutional structures of EMU's northern member states (Austria, Belgium, Finland, Germany, and the Netherlands). Countries adhering to this type of growth regime are generally small economies (Germany is an exception) with high levels of social expenditure and are highly open to international trade (Katzenstein, 1985). Because national production is concentrated in industries where firms are price takers in international markets, countries belonging to this export-led growth regime generally possess co-ordinated wage-bargaining institutions that deliver (nominal) wage moderation, keeping unit labour costs and inflation low.

In line with the Varieties of Capitalism literature, these (co-ordinated market) economies have remained successful in maintaining the size of their export sectors amidst globalization and European integration because they possess institutions which promote the accumulation of skills conducive to high value-added production (Streeck, 1997; Hall and Soskice, 2001). Specialization in high value-added production shields their firms from more intense globalized competition in low-skilled manufacturing that precipitated decline in the manufacturing sectors of southern European 'mixed market' and (Britain's) 'liberal market' economies (Rhodes, 2000). While the moderation of nominal wages within export-driven nation states limits growth in domestic demand, the more substantial size of the export sector relative to the domestic sector overcompensates for this, producing aggregate (export-driven) economic and employment growth (Dullien, 2003).

Unlike export-led capitalist growth regimes, domestic demand-led models are supported by political coalitions in the domestic non-traded sector. Countries adhering to this type of growth regime are usually large and/or have trade shares that are substantially smaller than the size of the domestic economy. These political economies generally lack co-ordinated labour market and industrial relations institutions that deliver substantial wage moderation. Within EMU, domestic demand-driven models cluster in southern Europe's 'low-productivity', 'mixed market' economies, whose conflict-prone, wagesetting and collective bargaining institutions are predisposed to high inflation and trade/current account deficits vis-à-vis their export-led neighbours.

\footnotetext{
${ }^{6}$ We ignore Eastern European countries because they joined EMU at the onset (Slovenia in 2007, and Cyprus and Malta in 2008) or after the 2008 financial crisis, when north and south external divergences were most pronounced.
} 
Ireland presents a temporal contrast to this export-led versus demand-oriented growth model distinction. The country realigned itself to a strong export-driven growth regime in 1987 with the conclusion of the Programme for National Recovery (PNR). Contrary to 'purer' liberal market economies (LMEs) that abandoned centralized wage-setting in the 1980s, Ireland re-instituted centralized wage bargaining in the PNR in order to produce (nationwide) competitiveness-enhancing wage restraint, leading to an export-led economic recovery (Culpepper and Regan, 2014). But this period of cost competitiveness was short-lived. During the late 1990s and early and mid-2000s, Ireland's banking, construction and public sectors, in addition to pro-cyclical fiscal policies by centre-right populist governments, drove the economy back to the inflation-prone domestic demand-driven model that had existed previously. Since the onset of the crisis, Ireland has re-prioritized its export-led growth model through an active state developmental enterprise policy aimed attracting US foreign direct investment in high tech growth sectors via low corporate taxes, light touch regulation and open labor markets (Regan, 2014).

France, which oscillated between current account deficits in the 1980s and current account surpluses in the 1990s, also presents a slightly different variation of the domestic demand-led growth model, because its wage developments conform more to those of its export-driven northern neighbours than its southern demand-driven ones. While France's domestic non-traded sector is larger than its export sector, it is less prone to inflation than southern European countries because the state (rather than autonomous social partners) guarantees wage moderation through state-imposed wage co-ordination. Moderated wage settlements in large multinational corporations (MNCs) are legally extended by the Ministry of Labour to the majority of the private sector and are subsequently used as the benchmark by the government in public sector bargaining (Hancké, 2002).

It is important to note that despite EMU's demand-led peripheral member states being more inflation-prone, they too witness lower unit labour cost growth in their tradable manufacturing sectors, which are exposed to international competition. It is the absence of wage moderation in their non-tradable sectors that places upward pressure on national prices, leaving export-oriented firms with an inflationary disadvantage vis-à-vis northern European exporters (see Herrmann, 2005). For example, in 2007, the hourly wage in the non-market services sector (which encompasses health and social work, education and public administration and defence) in Italy, Spain, Ireland and Portugal was 38 per cent, 24 per cent, 50 per cent and 120 per cent higher, respectively, than the hourly wage in the manufacturing sector (EU KLEMS, 2010). In contrast, the hourly wage in the nonmarket service sector of the EMU's northern export-oriented economies was either at parity with (the Netherlands) or below (Austria, Belgium, France, Finland and Germany) that in manufacturing.

Because domestic demand-led economies are more inflation-prone than their export-led counterparts, ceteris paribus, their firms will always hold a more disadvantageous inflation position when competing with firms in export-led economies. ${ }^{7}$ However, this higher inflation penalty does not necessarily translate into worsened external balances vis-à-vis export-led countries, as inflation's influence on the real exchange rate (the nominal exchange rate multiplied by the ratio of the domestic price level, relative to the price level

\footnotetext{
${ }^{7}$ In the interest of parsimony, we ignore differences in exposure to international price shocks and international capital mobility, which influence inflation differentials between export and domestic demand-led growth models.
} 
of a country's trading partners) may be offset by changes in the nominal exchange rate. In some currency regimes, the nominal exchange rate and domestic inflation do not move in tandem, meaning that an increase in one will be offset by a decrease in the other. Europe's single currency changed all of this as it removed two crucial tools of adjustment between high and low inflation-prone growth regimes: the nominal exchange rate and national central banks.

\section{Inflation Adjustment Mechanisms in Different Currency Regimes}

In order to conceptualize how the tools of political intervention (by national governments and central banks) in currency regimes outside of monetary union limit external imbalances between growth models in the eurozone, it is necessary to differentiate between two currency regime types: hard currency or fixed exchange rate systems, where nominal exchange rate realignment is limited (managed by national central banks); and soft currency or flexible exchange rate systems, where nominal exchange rate realignment/movement gives countries greater capacity to adjust for domestic price increases (government intervention). ${ }^{8}$ Both of these monetary regimes facilitated competitive realignment in Europe between export-led and domestic demand-led growth models, but they differ in how they achieved this realignment.

Soft currency and flexible exchange rate systems promote competitive and external borrowing realignment through nominal exchange rate depreciation/devaluation and appreciation/revaluation. When nation states possess their own currencies in this monetary regime, adjustments to price imbalances occur automatically via the nominal exchange rate. Currencies in (inflation-prone) domestic demand-led growth models lose their value relative to countries with low inflation, thereby compensating for the lack of price competitiveness in the real exchange rate. (Table 1 provides average nominal exchange rate appreciations for EMU countries during the 1980s and 1990s. In domestic demand-led economies, higher inflation rates correspond with greater depreciations of the average nominal exchange rate). These devalued currencies also produce higher exchange rate risk premiums in international markets, thereby triggering higher interest rates which limit the scale of external borrowing. Likewise, the price of the currency in export-driven growth regimes, which have the institutional capacity to produce lower levels of inflation via wage moderation, gains in nominal value (i.e. appreciates). This increase in the price of their currency undercuts the price competitiveness in their real exchange rate. These appreciated currencies also produce lower exchange rate risk premiums, leading to lower interest rates, which, ceteris paribus, enhances demand for external borrowing. In other words, the direct influence of wage inflation on the real exchange rate is mitigated by nominal exchange rate movements.

In 1979 the EMS's ERM was created to put an end to a system of competitive devaluations and to institute an unaccommodating monetary regime. ${ }^{9}$ Several EU nation states committed to a hard-currency peg with the ECU (European Currency Unit), which was,

\footnotetext{
${ }^{8}$ We treat soft-peg and flexible exchange rate regimes similarly in this article, because the former, like the latter, is highly permissive in nominal exchange rate adjustment.

${ }^{9}$ National 'models' of capitalism shaped the politics behind this process of European monetary integration. The previous 'soft currencies' wanted access to capital flows, whereas the 'hard currencies' wanted access to stable markets.
} 
Table 1: Nominal Exchsange Rate Changes and Inflation Averages for the EMU11

\begin{tabular}{lcccc}
\hline & $\begin{array}{c}\text { Average Annual Change in the } \\
\text { Nominal Exchange Rate }\end{array}$ & $\begin{array}{c}\text { Average Annual Change } \\
\text { in Inflation }\end{array}$ \\
\hline & $1980 \mathrm{~s}$ & $1990-1998$ & $1980 \mathrm{~s}$ & $1990-1998$ \\
Austria & $2.41 \%$ & $1.40 \%$ & $3.84 \%$ & $2.61 \%$ \\
Belgium & $-0.56 \%$ & $1.33 \%$ & $4.90 \%$ & $2.26 \%$ \\
Finland & $1.43 \%$ & $-1.27 \%$ & $7.32 \%$ & $2.24 \%$ \\
Germany & $2.89 \%$ & $2.00 \%$ & $2.90 \%$ & $2.73 \%$ \\
The Netherlands & $1.84 \%$ & $1.32 \%$ & $3.00 \%$ & $2.60 \%$ \\
Export-led average & $\mathbf{1 . 6 0} \%$ & $\mathbf{0 . 9 6} \%$ & $\mathbf{4 . 3 9} \%$ & $\mathbf{2 . 4 9} \%$ \\
& & & & \\
Greece & $-11.67 \%$ & $-4.83 \%$ & $19.50 \%$ & $12.05 \%$ \\
Italy & $-2.41 \%$ & $-1.45 \%$ & $11.20 \%$ & $4.38 \%$ \\
Portugal & $-8.83 \%$ & $-0.87 \%$ & $17.35 \%$ & $6.59 \%$ \\
Spain & $-2.34 \%$ & $-1.57 \%$ & $10.26 \%$ & $4.44 \%$ \\
Domestic demand-led average & $-\mathbf{6 . 3 1} \%$ & $-\mathbf{2 . 1 8} \%$ & $\mathbf{1 4 . 5 8} \%$ & $\mathbf{6 . 8 7 \%}$ \\
& & & & \\
France & $-1.69 \%$ & $1.92 \%$ & $7.38 \%$ & $2.06 \%$ \\
Ireland & $-1.33 \%$ & $0.50 \%$ & $9.34 \%$ & $2.39 \%$ \\
Oscillating demand/export economies & $-\mathbf{1 . 5 1} \%$ & $\mathbf{1 . 2 1} \%$ & $\mathbf{8 . 3 6} \%$ & $\mathbf{2 . 2 3} \%$ \\
average & & & & \\
\hline
\end{tabular}

Source: EU AMECO Database (2014)

Note: Positive changes in the nominal exchange rate imply currency appreciations/depreciations.

de facto, centred on the German mark. Given the priority of the export sector within their growth models, the EMS's small open trading nations made the transition to the ERM earlier, in order to deliver stability to their exchange rates. The Netherlands entered the ERM with a hard-currency policy already in place. Likewise, Austria established a unilateral hard-peg with the German mark in the late 1970s (Hochreiter and Winckler, 1995). Belgium committed to a hard-peg slightly later and initiated its last significant external devaluation in 1983, while France and Ireland undertook their last significant devaluations in 1986 and 1992, respectively (McNamara, 1998, p. 142; Enderlein, 2006; Kelly, 2003). Finland presents a slight deviation from its export-led neighbours. Between 1979 and the late 1980s, it pursued a highly permissive soft-currency peg with a basket of currencies (the German mark had a dominant weight) that resulted in the markka losing 60 per cent of its value relative to the German mark between the mid-1970s and 1989 (Genberg, 2004). Finland briefly attempted a hard-peg with the ECU between 1991 and 1992, but the ERM crisis, coupled with a severe recession, forced it to exit the arrangement. It did not rejoin until 1996.

Due to their higher inflation rates, EMU's southern member states entered the hard-currency peg of the ERM much later, and with very different domestic institutions. Spain joined in 1989 with a wider fluctuation band of \pm 6 percent; Portugal entered in 1992 also with a \pm 6 percent fluctuation margin, and Greece finally initiated its adjustment toward a hard-currency regime in 1994 (Ungerer et al., 1990; Tavlas and Papaspyrou, n.d.). Italy failed to transfer to the narrow \pm 2.25 percent fluctuation bands until 1990 (Ungerer et al., 1990). During the 1980 s, these southern European member states had significantly higher inflation 
rates relative to their export-led northern neighbours, but the political tool of currency depreciation/devaluation compensated for the negative impact of inflation on the real exchange rate, limiting the growth of external imbalances between these diverse growth models (see Table 1).

\section{From Hard-Currency Adjustment to Monetary Union}

The same co-existence of growth regimes occurred in hard-peg fixed exchange rate systems. This currency regime promoted the co-existence of export-led and domestic demand-driven growth models in Europe by way of inflation convergence. Such inflation convergence is only possible, however, in the presence of national central banks that respond to domestic price developments through direct targeting of the real exchange rate. Under a fixed exchange rate regime, the pursuit of independent monetary policy is not possible (Mundell, 1961; Fleming, 1962) and national banks must target the inflation performance of the anchor currency. ${ }^{10}$ This hard-peg obligation limits the political intervention of national governments to use currency devaluations for competitive realignment. Central banks in domestic demand-led models cannot respond to high inflation with nominal exchange rate adjustments under this currency regime; therefore they must respond to high inflation with monetary contraction (McNamara, 1998).

The enforcement of a hard-currency policy through monetary contraction as conducted by national central banks was relatively successful at producing inflation convergence between export-led and domestic demand-led growth models within Europe. This convergence was institutionalized at the European level with the Maastricht nominal criteria between 1992 and 1998. In order to fulfil inflation requirements for EMU entry and commit to a de facto hard-peg regime, many Member States, particularly in southern Europe, instituted painful downward adjustments in wages and public spending through national 'social pacts' between governments, unions and employers (Johnston, 2012). These domestic adjustment processes delivered a low inflation regime to southern European economies via close co-ordination of wage, fiscal and monetary policy. Although the nominal exchange rate was fixed, inflation convergence in the 1990s ensured convergence in real exchange rates between EMU's export-led and domestic demand-led models, which limited divergence in current account balances and continued to facilitate the co-existence of growth regimes.

The creation of the EMU eliminated both adjustment mechanisms in the soft-peg and hard-peg arrangements. Under a common currency, the nominal exchange rate disappeared, eliminating its role as an adjustment mechanism for taming diverging inflation performances in the real exchange rate. Monetary union's new real exchange rate identity, which became solely a function of relative inflation, provided export-led countries in northern Europe with a persistent competitive advantage in the real exchange rate given their persistent low inflation performances. Furthermore, while countries in hard and unaccommodating currency regimes lacked the nominal exchange rate as an adjustment mechanism, the institutional feature that facilitated the convergence of inflation and real exchange rates between different European varieties of capitalism - national central banks - also disappeared. The European Central Bank

\footnotetext{
${ }^{10}$ Of course, the anchor currency could be exposed to price shocks, which would lead to higher inflation. In this case, however, the shadow currency would need to follow such inflation developments in order to uphold the peg.
} 
(ECB) targeted average inflation rates across very different political economies and possessed limited capacity to deliver inflation convergence among diverse EMU member states. Consequently, it could not use a one-size-fits-all monetary policy to enforce low inflation in those member states with demand-led growth models like its national central bank predecessors had done previously.

The absence of national central banks aimed at promoting inflation convergence had immediate effects on the real exchange rate. Inflation and the real exchange rate slowly but persistently diverged between EMU's export-led and demand-led growth regimes. This was not due to the resurgence in wage inflation in domestic demand-led economies per se. EMU's peripheral states witnessed lower inflation rates in the pre-crisis 2000s than they did in the 1990s. Rather, it was largely facilitated by severe wage moderation and deflation in the co-ordinated market economies of northern Europe, which were most prominent in Germany. In 1999, inflation differentials between EMU's northern and southern economies were roughly 2 per cent. By 2001, these inflation differentials had doubled (EU AMECO Database, 2014). Such inflation differentials accumulated year on year and transpired into a persistent divergence in the real exchange rate.

European monetary integration did not achieve its political objective of economic and institutional convergence among participating member states. EMU contributed to the imbalance of capitalisms by establishing an environment where persistent divergence in the real exchange rate and, in turn, growing external imbalances between the north and south of Europe were possible. The biggest losers of European monetary integration were not the social market economies of northern Europe, with historically specific export-led growth regimes, but those EMU member states lacking CME institutional foundations. Below, we test our argument on the incompatibility of growth regimes within the euro area with a formal empirical model.

\section{Empirical Evidence from the EU14: Currency Regimes, Inflation Performance, and External Balances}

We use a cross-sectional, time-series regression of the EU14 ${ }^{11}$ from 1980 to 2012 to examine how different currency regimes interact with conflicting components of the real exchange rate (inflation and the nominal exchange rate) in influencing a member state's current account balance. We seek to determine under which currency regime(s) does inflation produce persistent current account imbalances. We expand our sample to the EU14's non-EMU countries (Denmark, Sweden and the UK) in order to capture variation in current account, inflation and the nominal exchange rate after 1999, but we are also forced to limit our sample to these countries, because the national nominal exchange rate index data we use is constructed relative to the EU15.

The current account is composed of a country's net exports (the largest item), net income from abroad and net transfers of assistance. Rather than modelling the current account as a function of the three items, we provide a simplified model that focuses more exclusively on variables that are directly linked to the movement of these components:

\footnotetext{
${ }^{11}$ These countries include Austria, Belgium, Denmark, Finland, France, Germany, Greece (which entered in 2001), Ireland, Italy, the Netherlands, Portugal, Spain, Sweden and the United Kingdom. We exclude Luxembourg as it was a member of a de facto currency union with Belgium prior to its EMU entry.
} 
the real exchange rate, which we separate into the nominal exchange rate and the inflation rate, and growth in (real) per capita incomes. We introduce a slight innovation into this simplified model, however, by examining the interaction between the three currency regimes outlined above and (the) nominal exchange rate/inflation. The purpose of this is to examine the influence of the nominal exchange rate and domestic inflation on the current account under different currency regimes and to identify monetary regimes where inflation performance leads to persistent improvements/decline in external balances.

Our baseline model can be summarized as follows:

$$
\begin{aligned}
\left(C A_{i, t}-\right. & \left.C A_{i, t-1}\right) \\
& =a_{i}+\beta_{1} N E R_{i, t}+\beta_{2} C P I_{i, t}+\beta_{3} E M U_{i, t}+\beta_{4} H A R D_{i, t}+\beta_{5}(E M U * N E R)_{i, t} \\
& +\beta_{6}(H A R D * N E R)_{i, t}+\beta_{7}(E M U * C P I)_{i, t}+\beta_{8}(H A R D * C P I)_{i, t} \\
& +\beta_{9} G D P P C_{i, t}+\varepsilon_{i, t}
\end{aligned}
$$

$\left(C A_{i, t^{-}} C A_{i, t-1}\right)$ is the first difference ${ }^{12}$ of country $i$ 's current account (as a percentage of GDP) at time $t, N E R_{i, t}$ is the (annual percentage change) in the nominal exchange rate of country $i$ at time $t$ and $C P I_{i, t}$ is the inflation rate of country $i$ at time $t . E M U_{i, t}$ is a dummy variable indicating whether a country is in monetary union at time $t . H A R D_{i, t}$ is a dummy variable indicating whether a country is subject to a hard-currency peg (i.e. fixed exchange rate arrangements with a restrictive \pm 2.25 per cent or lower fluctuation band) or the Maastricht nominal criteria at time $t$. The baseline (omitted) currency regime category, therefore, is a flexible/soft-currency peg exchange rate arrangement (Appendix A details which currency regime each EU14 country belonged to between 1980 and 2012). $\left(E M U^{*} N E R\right)_{i, t}$ and $\left(E M E^{*} C P I\right)_{i, t}$ are interactions between the EMU dummy and the nominal exchange rate and inflation rate, respectively. Likewise, $\left(H A R D^{*} N E R\right)$ $i, t$ and $\left(H A R D^{*} C P I\right)_{i, t}$ are interactions between the hard-peg/Maastricht currency regime dummy and the nominal exchange rate and inflation rate, respectively $G D P P C_{i, t}$ is real per capita GDP growth in country $i$ at time $t .{ }^{13}$

Because the flexible/soft-peg currency arrangement is the baseline category, effects of the nominal exchange rate and inflation on the current account under this currency regime are exhibited in the hierarchical terms $\beta_{1}$ and $\beta_{2}$ Because the nominal exchange rate counteracts inflation's influence on the real exchange rate in flexible/soft-peg exchange rate systems, we anticipate that neither the nominal exchange rate nor the inflation hierarchal terms will correlate directly with changes in the current account. A significant pair-wise correlation coefficient of -0.55 between the nominal exchange rate and inflation under the flexible/soft-peg system indicates that these two components work strongly against each other in the real exchange rate. In other words, we anticipate that both $\beta_{1}$ and $\beta_{2}$ will

\footnotetext{
${ }^{12}$ We take the first difference of the current account because a Hadri-LM unit root test indicated the current account balance (as a percentage of GDP) was non-stationary.

${ }^{13}$ Current account, nominal effective exchange rate and inflation data were taken from the EU's AMECO database, while real GDP per capita (in US dollars, purchasing power parity) data was taken from the OECD (2014).
} 
exhibit non-significance in explaining current account imbalances (hence, persistently higher inflation rates will not lead to persistent declines in external balances in softcurrency regimes). We also anticipate the hard-currency regime's interaction term with inflation $\beta_{8}$ will display non-significance, as the diverse growth models that engage in this currency arrangement converge in their inflation, and hence real exchange rate competitiveness, behaviour.

The hard-currency regime's interaction with the nominal exchange rate (whose effect is captured in $\beta_{6}$ ) and monetary union's interaction with the nominal exchange rate (which is effectively the euro exchange rate relative to the soft-peg baseline category), captured in $\beta_{5}$ may also display insignificance. Under both a hard-peg and single currency, the nominal exchange rate no longer provides an adjustment mechanism among its participants, because countries entering these currency regimes must, or do in the case of monetary union, converge in their nominal exchange rate behaviour. However, $\beta_{5}$ or $\beta_{6}$ may hold a significant negative coefficient, if joint increases in the nominal exchange rate of the hard currency or EMU regime prompt their members to lose exchange rate competitiveness en masse vis-à-vis countries that are participating within soft-currency arrangements. Joint increases in the (euro) nominal exchange rate, therefore, would prompt a decline in competitiveness and a reduction in the current account balance via countries that are not members of a hard-currency regime/currency union (more simply, if the nominal exchange rate of the euro currency appreciates, EMU countries become uncompetitive relative to Denmark, Sweden and the UK, and their current accounts should deteriorate accordingly).

The direct influence of inflation on the current account should be conditional on the presence of monetary union. Because the real exchange rate between countries that share a similar currency is simply the ratio of prices between these countries, and because national central banks no longer exist to facilitate inflation convergence with the onset of monetary union, an increase in a country's inflation rate will lead to a higher real exchange rate and hence a reduction in the current account balance. Therefore, $\beta_{7}$ should be significantly associated with current account decline given inflation's direct effect on the real exchange rate under a common currency. If inflation's direct effect on the current account is conditional upon monetary union, and not under the other currency regimes, then low-inflation export-led growth regimes will persistently outperform high-inflation domestic demandgrowth models in their external balances only under Europe's common currency.

Finally, we include real GDP per capita growth as a control, given its negative relationship with the current account: as incomes increase, imports increase, leading to trade, and ultimately current account, deficits. In order to control for omitted time and country effects, we include (n-1) country and time dummies. While some have questioned the use of fixed effects, which have the potential to crowd out the explanatory power of time-invariant regressors (see Kittel and Winner, 2005), we include them in our model because our variables are stochastic and are not presented in levels (our results remain consistent when we use a random effects estimator). We also utilize country-clustered standard errors to correct for contemporaneous correlation and panel heteroscedasticity. ${ }^{14}$ The use of panel-corrected standard errors has

\footnotetext{
${ }^{14}$ A Wooldridge test for auto-correlation and an LR statistic of panel heteroscedasticity provide evidence that both firstorder serial correlation and panel heteroscedasticity were present in the baseline model (Model I in Table 2).
} 
become a popular remedy in political science for both of these problems (see Beck and Katz, 1995), yet we opt for clustered standard errors because they produce more unforgiving robust standard errors (see Rogers, 2003).

Table 2 presents our three models: one includes only the influence of the nominal exchange rate and its conditional interaction with monetary union and a hard-peg regime; one includes only the influence of inflation and its conditional interaction with monetary union and a hard-currency regime; and one includes both dynamics. Our results confirm our argument that monetary union led to persistent divergences in the external balances of EMU's diverse growth models, which exhibit different inflation performances. In soft-peg/flexible currency regimes, the (hierarchical) inflation and the nominal exchange rate variables display a non-significant relationship with changes in the current account. In this exchange rate regime, inflation precipitates a decline in the nominal exchange rate, mitigating both variables' direct effect on the current account.

Likewise, the interaction term between the hard-peg/Maastricht currency regime and the inflation rate is also not significant. This, too, is unsurprising, given that countries that enter hard fixed exchange rate arrangements witness inflation convergence and thus exhibit minimal differences in this component of the real exchange

Table 2: Direct and Conditional Effects of Inflation and the Nominal Effective Exchange Rate on Current Account Balances (EU14, 1980-2012)

\begin{tabular}{|c|c|c|c|}
\hline & $I$ & II & III \\
\hline$\triangle N E R$ & $\begin{array}{c}0.0156 \\
(0.030)\end{array}$ & & $\begin{array}{c}0.0095 \\
(0.023)\end{array}$ \\
\hline$\triangle C P I$ & & $\begin{array}{c}-0.0259 \\
(0.048)\end{array}$ & $\begin{array}{c}-0.0238 \\
(0.043)\end{array}$ \\
\hline EMU Dummy & $\begin{array}{c}0.0826 \\
(0.417)\end{array}$ & $\begin{array}{l}0.7866^{* *} \\
(0.399)\end{array}$ & $\begin{array}{l}0.8100^{* * *} \\
(0.380)\end{array}$ \\
\hline Hard-Peg Dummy & $\begin{array}{c}-0.1743 \\
(0.184)\end{array}$ & $\begin{array}{r}-0.2423 \\
(0.371)\end{array}$ & $\begin{array}{r}-0.1621 \\
(0.384)\end{array}$ \\
\hline$\triangle N E R{ }^{*}$ EMU Dummy & $\begin{array}{c}-0.2802^{* *} \\
(0.122)\end{array}$ & & $\begin{array}{c}-0.2568^{* *} \\
(0.119)\end{array}$ \\
\hline$\triangle N E R{ }^{*}$ Hard-Peg & -0.0338 & & -0.0252 \\
\hline Dummy & $(0.044)$ & & $(0.043)$ \\
\hline$\triangle C P I^{*}$ EMU Dummy & & $\begin{array}{c}-0.3450^{\text {****** }} \\
(0.118)\end{array}$ & $\begin{array}{c}-0.3274^{* * * *} \\
(0.110)\end{array}$ \\
\hline$\triangle C P I^{*}$ Hard-Peg & & 0.0053 & -0.0113 \\
\hline Dummy & & $(0.050)$ & $(0.051)$ \\
\hline$\triangle$ Real Per Capita Income & $\begin{array}{c}-0.2391^{* * * * *} \\
(0.044)\end{array}$ & $\begin{array}{c}-0.2287^{* * * *} \\
(0.048)\end{array}$ & $\begin{array}{c}\left.-0.2351^{*} \cdot{ }^{*} \cdot 0.044\right)\end{array}$ \\
\hline Constant & $\begin{array}{c}0.632 \\
(0.603)\end{array}$ & $\begin{array}{l}1.2288^{* * *} \\
(0.418)\end{array}$ & $\begin{array}{c}0.6948 \\
(0.499)\end{array}$ \\
\hline Number of observations & 448 & 448 & 448 \\
\hline$R$-squared (within panels) & 0.2207 & 0.2251 & 0.2362 \\
\hline
\end{tabular}

Note: The dependent variable is the first difference in the current account balance (as a percentage of GDP). The model used was a pooled cross-sectional time series OLS estimator for the EU14 from 1980 to 2012. N-1 country and time dummies are included but not shown. Country-clustered standard errors are provided in parentheses. *,**, and *** indicate significance at a $90 \%, 95 \%$, and $99 \%$ confidence level, respectively. 
rate. The interaction term between the EMU and the nominal exchange rate is negatively significant, indicating that increases in the euro's nominal exchange rate leads to a worsening of the current accounts of EMU countries vis-à-vis noneurozone countries. Even though the interaction term between the hard-currency peg and the nominal exchange rate was also negative, it was non-significant. The EMU dummy is also positively significant in two of the three models, indicating that countries are more likely to witness positive increases in the current account under monetary union, compared to a soft-currency regime.

Inflation's (negative) impact on the current account balance is only significant when interacted with monetary union. Keeping all else equal, if a country's inflation rate grows by 1 per cent in a given year under monetary union, this prompts a 0.3 per cent (of GDP) decline in the current account balance. Since domestic demandled growth economies in southern Europe produce consistently higher inflation than export-led economies in northern Europe, our results indicate that such divergent inflation performances will translate into persistent decline in the current account balance only under monetary union. Under hard and soft currency regimes, higher inflation rates do not translate into the persistent worsening of current account balances.

Real GDP per capita growth, like the interaction between monetary union and national inflation, exhibits a negative relationship with the change in the current account balance. This suggests that inflationary price developments in domestic demand-led growth models may produce two effects that worsen the current account under monetary union: inflation directly increases the real exchange rate, making these economies over-priced relative to their European neighbours; and, if buoyed by wage-setters' response to inflation, a higher real GDP per capita growth would further reinforce this downward pressure on the current account balance through increased imports. Real per capita GDP growth's negative influence also highlights the trajectory of 'adjustment' in the south after 2008. The austerity-induced collapse in incomes precipitated a collapse in import demand in these member states, which reversed their large pre-crisis current account deficits.

\section{Conclusion: The Future of European Integration and National Varieties of Capitalism}

Using the eurozone as a regional case study in international political economy, we have illustrated the incompatibility and asymmetric effects of joining together distinct capitalist growth regimes (export-led and domestic demand-led) into a monetary union. These growth models could co-exist in previous currency regimes because policy-makers had access to macroeconomic instruments of adjustment to tame the worst effects of price divergence. Without nominal exchange rate adjustments (in soft-currency regimes) and national central banks that actively targeted the real exchange rate (in hard-currency regimes), these divergent inflationary growth regimes witnessed the rise of persistent external imbalances between each other.

What does this mean for the political economy of European integration? Though the EU has implemented new forms of further macroeconomic integration in attempts to 
rectify the crisis (the recent banking union, the European semester and the European Stability Mechanism), these efforts ignore the fundamental adjustment problem that we have outlined in this article. As long as some member states possess domestic institutions that grant them a comparative advantage in producing low inflation, they will, de facto, have a persistent competitive advantage in the real exchange rate that is conducive toward the accumulation of current account surpluses. Even the creation of a fiscal union is unlikely to rectify such imbalances. While income transfers from prosperous to struggling regions might help offset some of the income losses from the current crisis, they will not compensate for the lack of inflation adjustment mechanisms that underpin the growing 'imbalance of capitalisms' between export-led and domestic demand-driven growth regimes in EMU. Contrary to neo-liberal arguments of flexible adjustment in a monetary union, the biggest losers from European monetary integration were not northern European economies with strong labour unions and rigid, highly co-ordinated wage-setting institutions but rather countries lacking these political institutions.

Does this mean that it is not possible to integrate diverse political economies into a single currency? Thus far, the policy response to the eurozone crisis has exacerbated the (unequal) asymmetry of integration, as it is almost exclusively focused on adjustment in those peripheral member states that came under pressure from sovereign bond markets. The eurogroup and the Troika, which is heavily influenced by the crisis-management preferences of EMU's northern member states, is indirectly managing income divergences via the uniform reduction of wages and public services in peripheral member states. This push toward 'convergence' is taking place under the banner of 'structural reform' but ignores the type of reforms, capacity building, investment and domestic institutions that have enabled northern European countries to develop their export-led growth and undercut their southern trading partners with beggar-thy-neighbour wage policies. The one-sided adjustment has produced significant deflationary effects for southern European countries and their domestic demand-led growth models, creating long-term social and employment consequences with unforeseen political repercussions.

While EMU's domestic demand-led models are forced to pursue painful austerity measures that have reduced inflation and increased unemployment, no attempt has been made to correct the excessive levels of wage moderation in the EMU north, specifically Germany, which so undermined the periphery's lack of competitiveness in the euro's first decade. The result of the EU's policy response, which has been shaped in the shadow of German hierarchy, has been to establish an asymmetric low-growth equilibrium within Europe that exclusively penalizes its southern rim. The collapse of import demand in the periphery has partially corrected their current account imbalances, but export-led economies continue to pursue low-inflation strategies in an effort to sustain their current account surpluses. If Europe is to see an end to its current crisis and the incompatibility of its diverse growth regimes, it must address the deflationary bias within its monetary union that grants export-led member states persistent comparative advantage in their real exchange rates. Consideration must be given to the co-ordination of more robust wage growth and domestic demand in its northern economies. This would require the European Commission and the ECB to directly challenge the policy preferences of northern European countries in the Council. 
Correspondence:

Alison Johnston

Oregon State University

330F Ballard Hall

Corvallis, OR 97331.

email: Alison.Johnston@oregonstate.edu

\section{Appendix A:}

Appendix A. Currency Regime Membership for the EU14, 1980-2012

\begin{tabular}{|c|c|c|c|}
\hline Country & $\begin{array}{l}\text { Soft-peg/Flexible } \\
\text { System }\end{array}$ & $\begin{array}{c}\text { Hard Currency/ Maastricht } \\
\text { System }\end{array}$ & MonetaryUnion \\
\hline Austria & NA & $\begin{array}{l}\text { 1979-1995 (unilateral peg with } \\
\text { Germany); 1995-1998 (ERM } \\
\text { and Maastricht) }\end{array}$ & 1999-2012 \\
\hline Belgium & $1980-1983$ & $1984-1998$ & 1999-2012 \\
\hline Denmark & 1980-1982 & 1983-2012 & NA \\
\hline Finland & 1980-1990, 1992-1994 & $1991,1995-1998$ & 1999-2012 \\
\hline France & $1980-1986$ & 1987-1998 & 1999-2012 \\
\hline Germany & NA & 1980-1998 & 1999-2012 \\
\hline Greece & $1980-1993$ & $1994-2000$ & 2001-2012 \\
\hline Ireland & $1980-1986$ & $1987-1998$ & 1999-2012 \\
\hline Italy & $1980-1990$ & $1991-1998$ & 1999-2012 \\
\hline Netherlands & NA & $1980-1998$ & 1999-2012 \\
\hline Portugal & 1980-1991 & 1992-1998 & 1999-2012 \\
\hline Spain & $1980-1991$ & 1992-1998 & 1999-2012 \\
\hline Sweden ${ }^{\dagger}$ & 1980-1990, 1993-2012 & 1991-1992 & NA \\
\hline United Kingdom & $1980-2012$ & NA & NA \\
\hline
\end{tabular}

Sources: Hochreiter and Winckler, 1995; Enderlein, 2006; Genberg, 2004; Kelly, 2003; McNamara, 1998, 2005; Ungerer et al., 1990; Tavlas and Papaspyrou (n.d.). † Sweden joined the ERM briefly in 1991, exiting after the 1992 ERM crisis, and maintained a narrow $\pm 1.5 \%$ fluctuation band (Svensson, 1994). $\$$ The UK is classified as a soft-peg during its brief membership in the ERM in the early 1990s, because of its wider fluctuation margin of $\pm 6 \%$ (Ungerer et al., 1990).

\section{References}

Beck, N., and Katz, J. (1995) 'What to Do (And Not to Do) with Time-Series Cross-Section Data'. American Political Science Review, Vol. 89, No. 3, pp. 634-648.

Belke, A. and Dreger, C. (2011) 'Current Account Imbalances in the Euro Area: Catching up or Competitiveness'. RUHR Economic Papers, pp. 4-24.

Buiter, W., and Rahbari, E. (2010) 'Greece and the fiscal crisis in the Eurozone'. CEPR Policy Insight, pp. 1-15.

Burda, M. (2013) 'The European debt crisis: How did we get into this mess? How can we get out of it?' SFB Discussion Paper, No. 2013-019. Available at «http://www.econstor.eu/bitstream/ 10419/79629/1/745234356.pdf».

Culpepper, P. and Regan, A. (2014) Why don't governments need trade unions anymore? The death of social pacts in Ireland and Italy. Socio-Economic Review doi: 10.1093/ser/mwt028 First published online: February 2, 2014. 
Dullien, S. (2003) 'Is small really beautiful?: Explaining different unemployment performances within the Euro-zone'. European Political Economy Review, Vol. 1, No. 2, pp. 126-151.

Enderlein, H. (2006) 'Adjusting to EMU: The impact of supranational monetary policy on domestic fiscal and wage setting institutions'. European Union Politics, Vol. 7, No. 1, pp. 113-140.

European Commission's Directorate General for Economic and Financial Affairs (2014) Annual macro-economic database (AMECO), February-May 2014. Available at «http://ec.europa.eu/ economy_finance/ameco/user/serie/SelectSerie.cfm».

EU KLEMS Database (2010) Groningen Growth and Development Centre, December 2009-April 2011. Available at «http://www.euklems.net».

Fleming, M. (1962) 'Domestic Financial Policies under Fixed and under Floating Exchange Rates'. Staff Papers - International Monetary Fund, Vol. 9, No. 3, pp. 369-380.

Genberg, H. (2004) 'Monetary Policy Strategies after EU Enlargement' Paper prepared for the Conference on 'Challenges for Central Banks in an Enlarged EMU', Vienna, February 20-21, 2004. Available at «http://www2.wu-wien.ac.at/ecsa/emu/papgenberg.pdf».

Gros, D. (2012) 'Macroeconomic Imbalances in the Euro Area: Symptom or cause of the crisis'. CEPS Policy Brief

Hall, P. (2012) 'The Economics and Politics of the Euro Crisis'. German Politics, Vol. 21, No. 4, pp. 355-371.

Hall, P., and Soskice, D. (2001) Varieties of Capitalism: The Institutional Foundations of Comparative Advantage (Oxford: Oxford University Press).

Hancké, B. (2002) Large firms and institutional change: Industrial renewal and economic restructuring in France (Oxford: Oxford University Press).

Herrmann, A. (2005) 'Converging Divergence: How Competitive Advantages Condition Institutional Change under EMU'. Journal of Common Market Studies, Vol. 43, No. 2, pp. 287-310.

Hochreiter, E. and Winckler, G. (1995) 'The Advantages of Tying Austria's Hands: The Success of the Hard Currency Strategy'. European Journal of Political Economy, Vol. 11, pp. 83-111.

Höpner, M. (2013) Die Verschiedenheit der europäischen Lohnregime und ihr Beitrag zur Eurokrise: Warum der Euro nicht zum heterogenen Unterbau der Eurozone passt. Max Planck Institute for the Study of Societies Discussion Paper 2013/5.

Johnston, A. (2012) 'European Economic and Monetary Union's Perverse Effects on Sectoral Wage Inflation: Negative Feedback Effects from Institutional Change?' European Union Politics, Vol. 13, No. 3, pp. 345-366.

Johnston, A., Hancké, B. and Pant, S. (2014) 'Comparative Institutional Advantage in Europe's Sovereign Debt Crisis'. Comparative Political Studies, Vol. 47, No. 13, pp. 1771-1800.

Jones, E. (2014) 'Competitiveness and the European Financial Crisis'. Conference paper presented at the $21^{\text {st }}$ Conference of Europeanists, Washington DC, March, 2014.

Jones, E. (2015) 'The Forgotten Financial Union'. In Matthijs M. and Blyth M. (eds) The Future of the Euro, pp. 44-69.

Katzenstein, P. (1985) Small states in world markets: Industrial Policy in Europe (Ithaca, New York: Cornell University Press).

Kelly, J. (2003) 'The Irish Pound: From Origins to EMU', Spring 2003 Quarterly Burden, Irish Central Bank. Available at «http://www.centralbank.ie/publications/Documents/2003\% 20Spring\%20-\%20Signed \%20Article\%20-\%20The\%20Irish\%20Pound\%20-\%20From\%20 Origins \%20to\%20EMU.pdf».

Kittel, B., and Winner, H. (2005) 'How Reliable is Pooled Analysis in Political Economy? The Globalization-Welfare State Nexus Revisited'. European Journal of Political Research, Vol. 44, pp. 269-293.

Lane, P. (2012) 'The European Sovereign Debt Crisis'. Journal of Economic Prespectives, pp. 49-68.

McNamara, K. (1998) The Currency of Ideas: Monetary Politics in the European Union (Ithaca: Cornell University Press). 
McNamara, K. (2005) 'European Monetary Union'. In Wallace, Wallace, and Pollack (eds) Policy-Making in the European Union (Oxford: Oxford University Press).

Mundell, R. (1961) 'A theory of optimum currency areas'. American Economic Review, Vol. 51, No. 4, pp. 657-665.

Obstfeld, M., and Rogoff, K. (2009) 'Global Imbalances and the Financial Crisis: Products of Common Causes'. Available at «http://www.parisschoolofeconomics.eu/IMG/pdf/BdF-PSEIMF_paper_OBSTFELD-ROGOFF.pdf».

OECD (2014) Main Economic Indicators, OECD. May, 2014. Available at «http://stats.oecd. org/mei/».

Regan, A. (2014) What Explains Ireland's Fragile Recovery from the Crisis? The Politics of Comparative Institutional Advantage. CESifo Forum, Vol. 15, No. 2, pp. 26-31.

Rhodes, M. (2000) 'Restructuring the British Welfare State: Between Domestic Constraints and Global Imperatives'. In Scharpf F. and Schmidt V. (eds.) Welfare and Work in the Open Economy: Diverse Responses to Common Challenges (Oxford: Oxford University Press).

Rogers, W. (2003) 'Regression Standard Errors in Clustered Samples'. STATA Technical Bulletin, Vol. 3, pp. 88-94.

Scharpf, F. (2011) 'Monetary union, fiscal crisis and the pre-emption of democracy.' LEQS Paper p. 36.

Shambaugh, J., Reis, R., and Rey, H. (2012) 'The Euro's Three Crises'. Brookings Papers on Economic Activity. (Spring): 157-231.

Streeck, W. (1997) German capitalism: does it exist? Can it survive?. New Political Economy, Vol. 2, No. 2, pp. 237-256.

Svensson, L. (1994) 'Why exchange rate bands?: Monetary independence in spite of fixed exchange rates'. Journal of Monetary Economics, Vol. 33, No. 1, pp. 157-199.

Tavlas, G. and Papaspyrou, T. (n.d.) 'Monetary Policy in Greece on the Road to EMU,' Technical Report, Bank of Greece. Accessible at «http://www.bankofalbania.org/web/pub/ tavlas_papaspyrou_255_1.pdf».

Ungerer, H., Hauvonen, J., Lopez-Claros, A and Mayer, T. (1990) The European Monetary System: Developments and Perspectives (Washington D.C: International Monetary Fund). 